\title{
Rapid UV-Vis spectroscopy methods for quantification of ranitidine tablets
}

\author{
Métodos de espectroscopia rápida UV-Vis para quantificação de comprimidos de ranitidina
}

\author{
Patrícia Rijo ${ }^{1,2^{*}}$, Lara Ribeiro ${ }^{1}$, Marisa Nicolai ${ }^{1}$, Paula Pereira ${ }^{1,3,4}$, Célia Faustino ${ }^{2 *}$ \\ ${ }^{1}$ Center for Research in Biosciences \& Health Technologies (CBIOS), Universidade Lusófona de Humanidades e Tecnologias, \\ 1749-024 Lisboa, Portugal; ${ }^{2}$ Research Institute forMedicines (iMed.ULisboa), Faculty of Pharmacy, Universidade de Lisboa, \\ Av. Prof. Gama Pinto, 1649-003, Lisbon, Portugal; ${ }^{3}$ Center for Natural Resources and Environment (CERENA), Instituto \\ Superior Técnico (IST), Universidade de Lisboa, Av. Rovisco Pais, 1049-001 Lisboa, Portugal; ${ }^{4}$ EPCV-ULHT-Universidade \\ Lusófona de Humanidades e Tecnologias, 1749-024 Lisboa, Portugal
}

*corresponding authors / autores para correspondência: patricia.rijo@ulusofona.pt; cfaustino@ff.ulisboa.pt

\begin{abstract}
Ranitidine is a histamine H2-receptor antagonist that inhibits gastric acid secretion, commonly used in the treatment and prophylaxis of peptic ulcer and gastroesophageal reflux disease. Over-the-counter ranitidine hydrochloride tablets are available in several European countries as well as the US for the relief of indigestion and heartburn. Commercial tablets containing the equivalent of $150 \mathrm{mg}$ of ranitidine were analysed following extraction. Ranitidine is watersoluble, thus avoiding the use of organic solvents. Standard aqueous solutions of ranitidine hydrochloride were used to construct a calibration curve. This graduate laboratory experiment describes a simple, inexpensive, safe, and "green" procedure for the quantification of ranitidine tablets by UV spectrophotometry. The entire procedure provides an pedagogical opportunity to approach a realistic analytical scenario, typical of a quality control laboratory, by designing an attractive and engaging hands-on session. An average content of $148 \pm 1 \mathrm{mg}$ of ranitidine was determined using both standard addition and external calibration methods and results are in agreement with Pharmacopoeia.
\end{abstract}

Keywords: Analytical chemistry, ranitidine, drugs/pharmaceuticals, quantitative analysis, UV-Vis spectroscopy

\section{Resumo}

A ranitidina é um antagonista do receptor de histamina $\mathrm{H} 2$ que inibe a secreção de ácido gástrico, normalmente utilizado no tratamento e profilaxia da úlcera péptica e da doença do refluxo gastroesofágico. Os comprimidos de cloridrato de ranitidina estão disponíveis em vários países europeus e também nos EUA para o alívio da indigestão e da azia. Foram analisados comprimidos comerciais de $150 \mathrm{mg}$ de ranitidina que exigiu a extração do fármaco hidrossolúvel, evitando assim a utilização de solventes orgânicos. Foram utilizadas soluções aquosas do padrão de cloridrato de ranitidina para construir as curvas de calibração. Esta experiência descreve um procedimento verde simples, barato e não perigoso para a quantificação de comprimidos de ranitidina por espectrofotometria UV, podendo ser adaptado para o ensino laboratorial. O procedimento proporciona uma oportunidade pedagógica para lidar com um problema analítico real, típico de um laboratório de controlo de qualidade, utilizando uma amostra farmacêutica que transverte uma experiência simples numa sessão laboratorial contextualizada e atrativa. Foi determinado um teor médio de 148 $\pm 1 \mathrm{mg}$ de ranitidina utilizando tanto o método de adição padrão como o método de calibração externa e os resultados encontram-se em consonância com a Farmacopeia.

Palavras-chave: Química analítica, ranitidina, medicamentos/farmacêuticos, análise quantitativa, Espectroscopia UV-Vis 


\section{Introduction}

UV-Vis spectroscopy is a feasible and straightforward analytical tool routinely used with other assay techniques in the pharmaceutical industry in areas such as quality control and quality assurance (1). Several papers describing the quantification of analytical samples by UV spectrophotometry in the pharmaceutical, biotechnological, and environmental areas, as well as in the field of food and beverage, have been reported in the literature (2-21).

Highly conjugated organic compounds, including many drugs and biological macromolecules (e.g., proteins and nucleic acids) absorb light in the ultraviolet (UV)visible (vis) region of the electromagnetic spectrum. Quantitative analysis is based on the relationship between the degree of absorption and the concentration of the absorbing species in solution, mathematically described by the Beer-Lambert law, $A=\varepsilon l c$, where $A$ is the absorbance at a fixed wavelength, $\varepsilon$ is the absorption coefficient, $l$ is the path length and $c$ is concentration.

This experiment was conceived to introduce the technique of ultraviolet spectroscopy to undergraduate students in Pharmaceutical Organic Chemistry classes and describes a simple, inexpensive, and environmentally green (organic solvent-free) laboratory procedure for the quantitative assay of ranitidine, a histamine $\mathrm{H}_{2}$-receptor antagonist, in commercial 150 mg ranitidine tablets.

Ranitidine is a histamine $\mathrm{H}_{2}$-receptor antagonist that inhibits gastric acid secretion induced by histamine, pentagastrin, and other secretagogues. Ranitidine hydrochloride (Figure 1) is a white or pale yellow, water-soluble, crystalline powder.

Ranitidine is commonly used in the treatment and prophylaxis of peptic ulcer and gastroesophageal reflux disease, and also in other conditions where reduction of gastric secretion and acid output is desirable. It can also be administered with nonsteroidal anti-inflammatory

\section{Introdução}

A espectroscopia UV-Vis é uma técnica analítica simples e rápida, utilizada rotineiramente em conjunto com outras técnicas analíticas na indústria farmacêutica, em áreas como controlo e garantia de qualidade ${ }^{1}$. Diversos trabalhos têm descrito a quantificação de substâncias contidas em amostras, usando a técnica de espectrofotometria UV, nomeadamente nas áreas farmacêutica, biotecnológica e ambiental, bem como no âmbito dos produtos alimentares (2-21).

Compostos orgânicos conjugados, incluindo alguns fármacos e macromoléculas biológicas (por exemplo, proteínas e ácidos nucleicos) absorvem radiação na região do ultravioleta (UV)-visível (vis) do espectro eletromagnético. Esta análise quantitativa baseia-se na relação entre a absorção de radiação e a concentração da espécie absorvente, em solução, que é descrita matematicamente pela lei de Lambert-Beer, $\mathrm{A}=\varepsilon l c$, sendo A a absorvância num comprimento de onda fixo, $\varepsilon$ a absortividade molar, $l$ o percurso ótico e $c$ a concentração.

Esta experiência teve como objetivo a introdução da técnica de espectroscopia ultravioleta-visível a alunos que frequentam aulas de Química Orgânica Farmacêutica e descreve um procedimento laboratorial simples, barato e verde (sem solventes orgânicos) para o ensaio quantitativo de ranitidina, em comprimidos comerciais contendo $150 \mathrm{mg}$ do fármaco.

A ranitidina é um antagonista da histamina $\mathrm{H} 2$-receptor que inibe a secreção de ácido gástrico induzida pela histamina, pentagastrina e outros secretagogo. O cloridrato de ranitidina (Figura 1) é um pó cristalino, branco ou amarelo-pálido, solúvel em água.

A ranitidina é geralmente utilizada no tratamento e profilaxia da úlcera péptica e da doença do refluxo gastroesofágico, e também quando a redução da secreção gástrica e da produção de ácido é desejável. Também pode ser administrada com anti-inflamatórios<smiles>CN/C(=C\[N+](=O)[O-])NCCSCc1ccc(CN(C)C)o1</smiles>

Figure 1 - Ranitidine hydrochloride

Figura 1 - Cloridrato de ranitidina 
drugs (NSAIDs) to reduce the risk of ulceration. The usual dose of ranitidine is either $150 \mathrm{mg}$ twice a day or $300 \mathrm{mg}$ once a day, usually at night.

Several preparations of ranitidine hydrochloride are available over the counter (OTC) for the relief of indigestion and heartburn, including $150 \mathrm{mg}$ tablets. Each tablet for oral administration contains $168 \mathrm{mg}$ of ranitidine hydrochloride (equivalent to $150 \mathrm{mg}$ of ranitidine anhydrous free base).

Students are provided with $150 \mathrm{mg}$ ranitidine tablets and a stock solution of ranitidine hydrochloride for the preparation of ranitidine standard solutions to be used in the construction of a calibration curve. The ranitidine tablets must be subjected to pre-analytical treatment for selective extraction and dilution of ranitidine for subsequent quantification.

The mass $(\mathrm{mg})$ of ranitidine in the prescription tablet is determined from the calibration curve obtained, and the value is then compared with the label claim of the manufacturer according to the specifications of the Pharmacopeia. The official monographs of the European Pharmacopoeia (22) (and also the USP (23)) require that ranitidine tablets contain an amount of ranitidine hydrochloride $\left(\mathrm{C}_{13} \mathrm{H}_{23} \mathrm{ClN}_{4} \mathrm{O}_{3} \mathrm{~S}\right)$ equivalent to not less than $90.0 \%$ and not more than $110.0 \%$ of the (package) labelled quantity of ranitidine $\left(\mathrm{C}_{13} \mathrm{H}_{22} \mathrm{~N}_{4} \mathrm{O}_{3} \mathrm{~S}\right)$ (24).

The entire laboratory procedure is completed in a three-hour lab session and is ideally performed by students working in group. It provides students with an opportunity to solve an authentic analytical problem with a commercial pharmaceutical sample in a realistic and engaging lab session. Although originally intended for undergraduate Pharmaceutical Organic Chemistry students, the experiment is simple enough to be performed by undergraduate students within a general chemistry course. It is also suited for advanced high school chemistry students, as long as a suitable UV spectrophotometer is available.

\section{Materials and Methods}

\section{Reagents}

Ranitidine hydrochloride was obtained from SigmaAldrich and used as received. OTC ranitidine hydrochloride tablets labelled to contain $150 \mathrm{mg}$ of ranitidine were purchased from a local pharmacy. Absorbance measurements were performed ten times não esteróides (AINEs) para reduzir o risco de ulceração. A dose habitual de ranitidina é de $150 \mathrm{mg}$ duas vezes por dia ou $300 \mathrm{mg}$ uma vez por dia, geralmente à noite.

Comercialmente, estão disponíveis várias formulações de cloridrato de ranitidina, para o alívio da indigestão e da azia, incluindo os comprimidos de $150 \mathrm{mg}$. Cada comprimido para administração oral contém $168 \mathrm{mg}$ de cloridrato de ranitidina (equivalente a $150 \mathrm{mg}$ de base livre de ranitidina anidra).

São fornecidos aos estudantes comprimidos de 150 mg de ranitidina e uma solução mãe de cloridrato de ranitidina para a preparação de soluções padrão de ranitidina a serem utilizadas na construção de uma curva de calibração. Os comprimidos de ranitidina devem ser submetidos a tratamento pré-analítico para extração seletiva e diluição, para posterior quantificação.

A massa (mg) de ranitidina no comprimido é determinada, a partir da curva de calibração obtida, e o valor é comparado com o rótulo do fabricante, de acordo com as especificações da Farmacopeia. As monografias oficiais da Farmacopeia Europeia (22) (e também da USP (23)) declaram que os comprimidos de ranitidina contêm uma quantidade de cloridrato de ranitidina $\left(\mathrm{C}_{13} \mathrm{H}_{23} \mathrm{ClN}_{4} \mathrm{O}_{3} \mathrm{~S}\right)$ equivalente a não menos do que $90,0 \%$ e não mais do que $110,0 \%$ da quantidade rotulada de ranitidina $\left(\mathrm{C}_{13} \mathrm{H}_{22} \mathrm{~N}_{4} \mathrm{O}_{3} \mathrm{~S}\right)(24)$.

Todo o procedimento laboratorial é executado numa sessão de três horas de laboratório e é idealmente realizado por estudantes que trabalham em grupo. Deste modo, proporciona-se aos estudantes a oportunidade de lidar com um problema analítico real e a possibilidade de utilizar uma amostra farmacêutica, transformando a experiência numa sessão laboratorial atrativa e envolvente. Embora originalmente destinada a estudantes de Química Orgânica Farmacêutica, a experiência é suficientemente simples para ser realizada por estudantes de um curso de química geral e é também adequada para estudantes do ensino secundário, desde que esteja disponível um espectrofotómetro UV.

\section{Materiais e Métodos}

\section{Reagentes}

O cloridrato de Ranitidina foi obtido de Sigma-Aldrich e utilizado como recebido. Os comprimidos de cloridrato de ranitidina OTC com uma quantidade rotulada de $150 \mathrm{mg}$ de ranitidina foram comprados a uma farmácia local. Foram efetuadas medições de absorvância dez 
for blanks and in triplicate for standards and sample at $25{ }^{\circ} \mathrm{C}$ with an ultraviolet-visible spectrophotometer (Shimadzu UV-1603, Kyoto, Japan) using $1 \mathrm{~cm}$ length quartz cells. Distilled water (solvent) was used as the reference blank.

\section{Experimental procedure}

Standard addition and external calibration methods were performed to quantify ranitidine in commercial tablets.

Firstly, for the external calibration method, ranitidine hydrochloride was dissolved in water in order to prepare a $500.0 \mu \mathrm{g} \mathrm{mL}^{-1}$ stock solution, which was provided to the students. From the stock solution, students performed serial dilutions to prepare $25 \mathrm{~mL}$ ranitidine hydrochloride standard solutions with concentrations in the range $1.00-20.00 \mu \mathrm{g} \mathrm{mL} \mathrm{mL}^{-1}$ to be used in the construction of a calibration curve.

The preparation of the pharmaceutical sample was based on the assay described in Pharmacopeia $(22,23)$ for ranitidine tablets. Five $150 \mathrm{mg}$ ranitidine tablets were accurately weighed and crushed with a mortar and pestle. The resulting powder, equivalent to the average mass of one tablet, was dissolved in distilled water, with gentle stirring, to a final volume of $500 \mathrm{~mL}$. The solution was filtered and a 1:100 dilution of the filtrate was performed, leading to the pharmaceutical sample to be analysed, with theoretical ranitidine concentration of $3.00 \mu \mathrm{g} \mathrm{mL} \mathrm{m}^{-1}$.

For the standard addition method, $2.50 \mathrm{~mL}$ of the previously prepared sample solution $\left(3.00 \mu \mathrm{g} \mathrm{mL} \mathrm{mL}^{-1}\right)$ was added to a $25 \mathrm{~mL}$ volumetric flask and the standard solutions were mixed and diluted to (final) ranitidine hydrochloride concentrations in the range of 1.0-20.0 $\mu \mathrm{g} \mathrm{mL}{ }^{-1}$.

The UV absorption spectra of the ranitidine hydrochloride stock solution and pharmaceutical sample were recorded between 400 and $200 \mathrm{~nm}$, using distilled water as the reference blank, to compare the two profiles and determine the wavelength(s) of maximum absorbance. Absorption measurements of ranitidine hydrochloride solutions were performed in triplicate at the wavelengths of maximum absorption. vezes para os brancos e em triplicado para os padrões e amostra a $25{ }^{\circ} \mathrm{C}$ com um espectrofotómetro UV1603 ultravioleta-visível Shimadzu (Quioto, Japão), utilizando células de quartzo de $1 \mathrm{~cm}$ de comprimento e água destilada (solvente) como branco de referência.

\section{Procedimento experimental}

Foram efetuados métodos de adição padrão e calibração externa para quantificar a ranitidina em comprimidos comerciais.

Em primeiro lugar, no método de calibração externa, o cloridrato de ranitidina foi dissolvido em água a fim de preparar uma solução de mãe de $500,0 \mu \mathrm{g} \mathrm{mL}^{-1}$ que foi fornecida aos estudantes. A partir da solução mãe, os estudantes realizaram diluições em série para preparar soluções padrão de $25 \mathrm{~mL}$ de cloridrato de ranitidina com concentrações na gama de 1,00-20,00 $\mu \mathrm{g} \mathrm{mL}^{-1}$ para serem utilizadas na construção de uma curva de calibração.

A preparação da amostra farmacêutica foi baseada no ensaio descrito na Farmacopeia $(22,23)$ para comprimidos de ranitidina. Cinco comprimidos de ranitidina de $150 \mathrm{mg}$ foram ponderados com precisão e esmagados com um almofariz e pilão. Uma quantidade de pó equivalente ao valor médio da massa de um comprimido foi dissolvida em água destilada, com agitação suave, para um volume final de $500 \mathrm{~mL}$. A solução foi filtrada e foi realizada uma diluição de 1:100 do filtrado, levando a amostra farmacêutica a ser analisada, com concentração teórica de ranitidina de $3,00 \mu \mathrm{g} \mathrm{mL}^{-1}$.

Em segundo lugar, no método de adição padrão, a partir da solução de amostra previamente preparada $(3,00 \mathrm{~g}$ $\left.\mathrm{mL}^{-1}\right)$, foram adicionados $2,50 \mathrm{~mL}$ ao balão volumétrico de $25 \mathrm{~mL}$ e as soluções padrão foram misturadas e diluídas em concentrações de cloridrato de ranitidina na gama de $1,0-20,0 \mu \mathrm{g} \mathrm{mL} \mathrm{m}^{-1}$.

Os espectros de absorção UV da solução mãe de cloridrato de ranitidina e da amostra farmacêutica foram registados entre 400 e $200 \mathrm{~nm}$, utilizando água destilada como branco de referência, de modo a comparar os dois perfis e determinar o(s) comprimento(s) de onda de absorção máxima. As medições de absorção de soluções de cloridrato de ranitidina foram realizadas em triplicado, nos comprimentos de onda de absorção máxima. 
For accurate and precise quantification of the ranitidine content, the limit of detection (LOD) and the limit of quantification (LOQ) were determined (25). The LOD was determined using Equation 1, and the LOQ by Equation 2:

$$
\begin{aligned}
& \mathrm{LOD}=\frac{3.3 \sigma}{S} \\
& \mathrm{LOQ}=\frac{10 \sigma}{S}
\end{aligned}
$$

where $\sigma$ is the standard deviation of the absorbance readings of the blank and $\mathrm{S}$ is the slope of the calibration curve.

Thus, ten absorbance measurements of the blank were performed at the wavelength of maximum absorbance of ranitidine to ensure a relative standard deviation (RSD) of less than $10 \%$, as recommended by IUPAC (26).
Para a quantificação rigorosa e precisa do teor de ranitidina recorreu-se à determinação do limite de deteção (LOD), Equação 1, que corresponde à menor quantidade de analito detetável, e do limite de quantificação (LOQ), Equação 2, que por sua vez corresponde à menor quantidade de analito quantificável (25).

$$
\begin{aligned}
& \mathrm{LOD}=\frac{3.3 \sigma}{s} \\
& \mathrm{LOQ}=\frac{10 \sigma}{S}
\end{aligned}
$$

Sendo $\sigma$ o desvio padrão das leituras de absorvância do branco e $\mathrm{S}$ o declive da curva de calibração.

Desta forma foram realizadas dez medições de absorvância do branco, no comprimento de onda de máxima absorção da ranitidina, para garantir um desvio padrão relativo (RSD) inferior a $10 \%$, tal como é recomendado pela IUPAC (26).

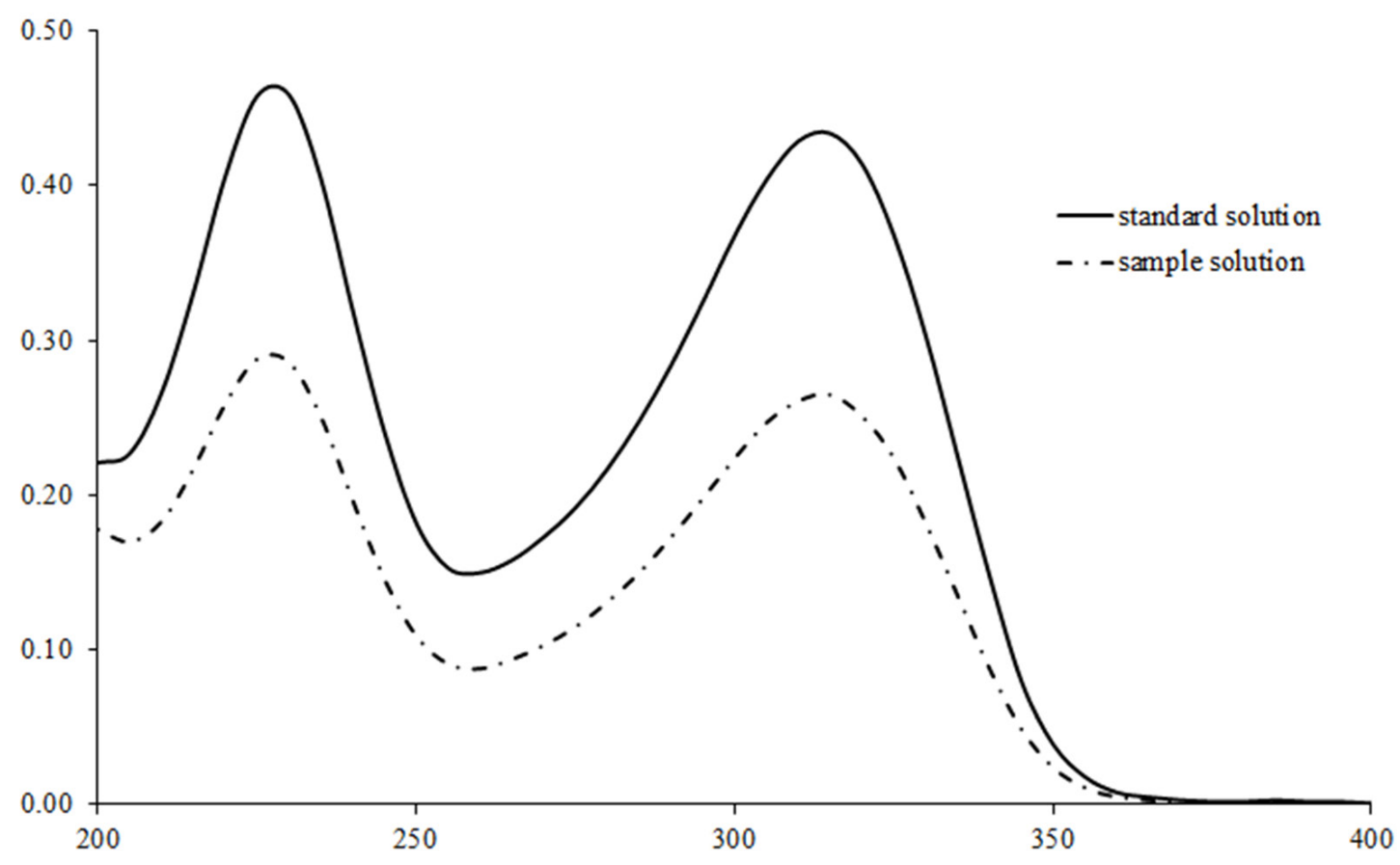

Figure 2 - UV absorption spectrum of a $10.0 \mu \mathrm{g} \mathrm{mL}^{-1}$ ranitidine hydrochloride stock solution (upper curve) and a solution from a commercial sample (lower curve) registered between 400 and $200 \mathrm{~nm}$.

Figura 2 - Espectro de absorção UV de uma solução mãe de $10,0 \mu \mathrm{g} \mathrm{mL} \mathrm{m}^{-1}$ de cloridrato de ranitidina (curva superior) e uma solução de uma amostra comercial (curva inferior) registada entre 400 e $200 \mathrm{~nm}$. 
Table 1 - Average absorbance (Abs), standard deviation $(\sigma)$ and relative standard deviation (RSD) of ranitidine hydrochloride solutions, at $227 \mathrm{~nm}$ and $314 \mathrm{~nm}$, for standard addition and external calibration methods

Tabela 1 - Absorvância média (Abs), desvio padrão $(\sigma)$ e desvio padrão relativo (RSD) de soluções de cloridrato de ranitidina, a $227 \mathrm{~nm}$ e $314 \mathrm{~nm}$, para os métodos de adição padrão e de calibração externa.

\begin{tabular}{|c|c|c|c|c|c|c|c|c|c|c|c|c|c|c|}
\hline \multirow[b]{2}{*}{ 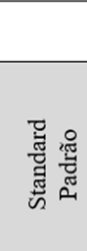 } & \multirow{2}{*}{ 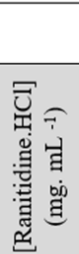 } & \multicolumn{7}{|c|}{$\begin{array}{l}\text { External calibration method } \\
\text { Método de calibração externo }\end{array}$} & \multicolumn{6}{|c|}{$\begin{array}{l}\text { Standard addition method } \\
\text { Método de adição de padrão }\end{array}$} \\
\hline & & 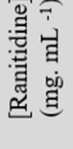 & $\begin{array}{l}\text { 䀚 } \\
\text { సิ } \\
2\end{array}$ & 0 & $\begin{array}{l}\frac{0}{2} \\
0 \\
\approx\end{array}$ & $\underset{2}{\stackrel{1}{2}}$ & 0 & $\begin{array}{l}0 \\
\frac{0}{2}\end{array}$ & 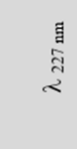 & o & $\frac{2}{2}$ & $\underset{\substack{1 \\
\stackrel{2}{2}}}{\stackrel{1}{2}}$ & 0 & $\begin{array}{l}\frac{2}{2} \\
\frac{2}{2}\end{array}$ \\
\hline $\mathrm{S} 1$ & 1 & 0.9 & 0.064 & 0.006 & 9.5 & 0.044 & 0.002 & 3.4 & 0.078 & 0.009 & 12.1 & 0.071 & 0.009 & 12.6 \\
\hline $\mathrm{S} 2$ & 2 & 1.8 & 0.093 & 0.008 & 8.2 & 0.085 & 0.004 & 4.2 & 0.123 & 0.01 & 8.0 & 0.112 & 0.006 & 5.7 \\
\hline S3 & 5 & 4.5 & 0.222 & 0.005 & 2.3 & 0.214 & 0.001 & 0.2 & 0.249 & 0.009 & 3.8 & 0.236 & 0.007 & 3.0 \\
\hline S4 & 10 & 9.0 & 0.480 & 0.029 & 6.1 & 0.438 & 0.034 & 7.7 & 0.520 & 0.042 & 8.0 & 0.486 & 0.024 & 4.9 \\
\hline S5 & 15 & 13.4 & 0.705 & 0.059 & 8.3 & 0.671 & 0.053 & 7.8 & 0.753 & 0.024 & 3.1 & 0.717 & 0.019 & 2.6 \\
\hline S6 & 20 & 17.9 & 0.947 & 0.059 & 6.2 & 0.899 & 0.053 & 5.9 & 1.008 & 0.011 & 1.1 & 0.957 & 0.011 & 1.1 \\
\hline \multicolumn{2}{|c|}{ Blank/Branco } & & 0.001 & 0.001 & 0.1 & 0.001 & 0.001 & 0.1 & 0.001 & 0.001 & 0.1 & 0.001 & 0.001 & 0.1 \\
\hline \multicolumn{2}{|c|}{ Sample/Amostra } & & 0.158 & 0.007 & 0.7 & 0.142 & 0.008 & 0.8 & & & & & & \\
\hline
\end{tabular}

\section{Results and Discussion}

The UV absorption spectra of the ranitidine hydrochloride stock solution and pharmaceutical sample solution are shown in Figure 2.

Sample and stock aqueous solutions show two absorption peaks at $314 \mathrm{~nm}$ and $227 \mathrm{~nm}$. Absorption measurements are then performed at $314 \mathrm{~nm}$ and 227 $\mathrm{nm}$ against distilled water as the reference blank. In order to quantify ranitidine in tablets, students must convert the amount of ranitidine chloride to the ranitidine free base. In solution, the absorbing species is ranitidine, with hydrogen chloride present (only) to stabilize the ranitidine molecule against oxidation. Typical average absorption values and corrected ranitidine concentrations are shown in Table 1.

From data shown in Table 1, calibration curves were prepared (Figure 3) by plotting absorption values against ranitidine concentration. A linear relationship between absorbance and concentration was observed in the studied concentration range of $0.9-17.9 \mu \mathrm{g} \mathrm{mL} \mathrm{mL}^{-1}$, thus following the Lambert-Beer law.

The equations of this straight line could be obtained from regression analysis using either a computer program or a scientific or graphing calculator in order to determine the ranitidine concentration $\left(\mu \mathrm{g} \mathrm{mL}^{-1}\right)$ in the sample solution and in the original pharmaceutical tablet, taking into account the dilution factor (Table 2).

The mass of ranitidine $(\mathrm{mg})$ in the prescription tablet was then determined from the concentration of ranitidine (mg/tablet) in the pharmaceutical sample and the value obtained is compared with the label claim of the manufacturer and with the specifications

\section{Resultados e Discussão}

Os espectros de absorção UV da solução mãe de cloridrato de ranitidina e da solução de amostra farmacêutica são mostrados na Figura 2.

As soluções aquosas de amostra e de mãe mostram dois picos de absorção a $314 \mathrm{~nm}$ e $227 \mathrm{~nm}$. As medições de absorção são então realizadas a $314 \mathrm{~nm}$ e $227 \mathrm{~nm}$ contra água destilada como branco de referência. Para quantificar a ranitidina em pastilhas, os estudantes têm de converter a quantidade de cloreto de ranitidina para a forma básica da ranitidina. Em solução, a espécie absorvente é a ranitidina, uma vez que a presença de cloreto de hidrogénio é apenas para estabilizar a molécula de ranitidina da oxidação. Os valores típicos de absorção média e concentração retificada de ranitidina são mostrados na Tabela 1 .

A partir dos dados da Tabela 1 são obtidas curvas de calibração (Figura 3) traçando os valores de absorção contra a concentração de ranitidina. Os gráficos de calibração da ranitidina obedeceram à lei Lambert-Beer na gama de concentrações estudada de 0,9-17,9 $\mu \mathrm{g} \mathrm{mL} \mathrm{L}^{-1}$, pelo que se observa uma relação linear entre absorção e concentração.

As equações desta linha reta podem ser obtidas a partir da análise de regressão utilizando um programa de computador ou uma calculadora científica ou gráfica, permitindo assim determinar a concentração de ranitidina $\left(\mu \mathrm{g} \mathrm{mL}^{-1}\right)$ na solução da amostra e no comprimido farmacêutico original, tendo em conta o fator de diluição (Tabela 2).

A massa de ranitidina $(\mathrm{mg})$ no comprimido prescrito é então determinada a partir da concentração de 
Table 2 - Quantification range, equation of calibration curve, square of correlation coefficient, limit of detection (LOD), limit of quantification (LOQ), ranitidine mass, relative error at $227 \mathrm{~nm}$ and $314 \mathrm{~nm}$ for external calibration and standard addition methods.

Tabela 2 - Gama de quantificação, equação da curva de calibração, quadrado do coeficiente de correlação, limite de deteção (LOD), limite de quantificação (LOQ), massa de ranitidina, erro relativo a $227 \mathrm{~nm}$ e $314 \mathrm{~nm}$ para os métodos de calibração externa e de adição padrão.

\begin{tabular}{|c|c|c|c|c|c|c|c|c|}
\hline & $\lambda(\mathrm{nm})$ & $\begin{array}{c}\text { Quantification } \\
\text { range } \\
\left(\mu g \mathrm{~mL}^{-1}\right)\end{array}$ & $\begin{array}{c}\text { Equation of } \\
\text { calibration curve }\end{array}$ & $\begin{array}{l}\text { Correlation } \\
\text { coefficient }\end{array}$ & $\begin{array}{c}L O D \\
\left(\mu g m L^{-1}\right)\end{array}$ & $\begin{array}{c}L O Q \\
\left(\mu g m L^{-1}\right)\end{array}$ & $\begin{array}{c}\text { Ranitidine } \\
\text { mass } \\
\text { (mg) }\end{array}$ & $\begin{array}{c}\text { Relative error } \\
\text { (\%) }\end{array}$ \\
\hline \multirow{2}{*}{$\begin{array}{c}\text { External calibration } \\
\text { method }\end{array}$} & 227 & \multirow{4}{*}{$0.9-17.9$} & $y=0.0525 x+0.0028$ & 0.9991 & 0.06 & 0.19 & 147.8 & -1.46 \\
\hline & 314 & & $y=0.0503 x+0.0066$ & 0.9998 & 0.07 & 0.22 & 147.7 & -1.52 \\
\hline \multirow{2}{*}{$\begin{array}{c}\text { Standard addition } \\
\text { method }\end{array}$} & 227 & & $y=0.0523 x+0.0153$ & 0.9997 & 0.05 & 0.19 & 146.3 & -2.49 \\
\hline & 314 & & $y=0.0523 x+0.0155$ & 0.9995 & 0.06 & 0.20 & 148.2 & -1.21 \\
\hline
\end{tabular}
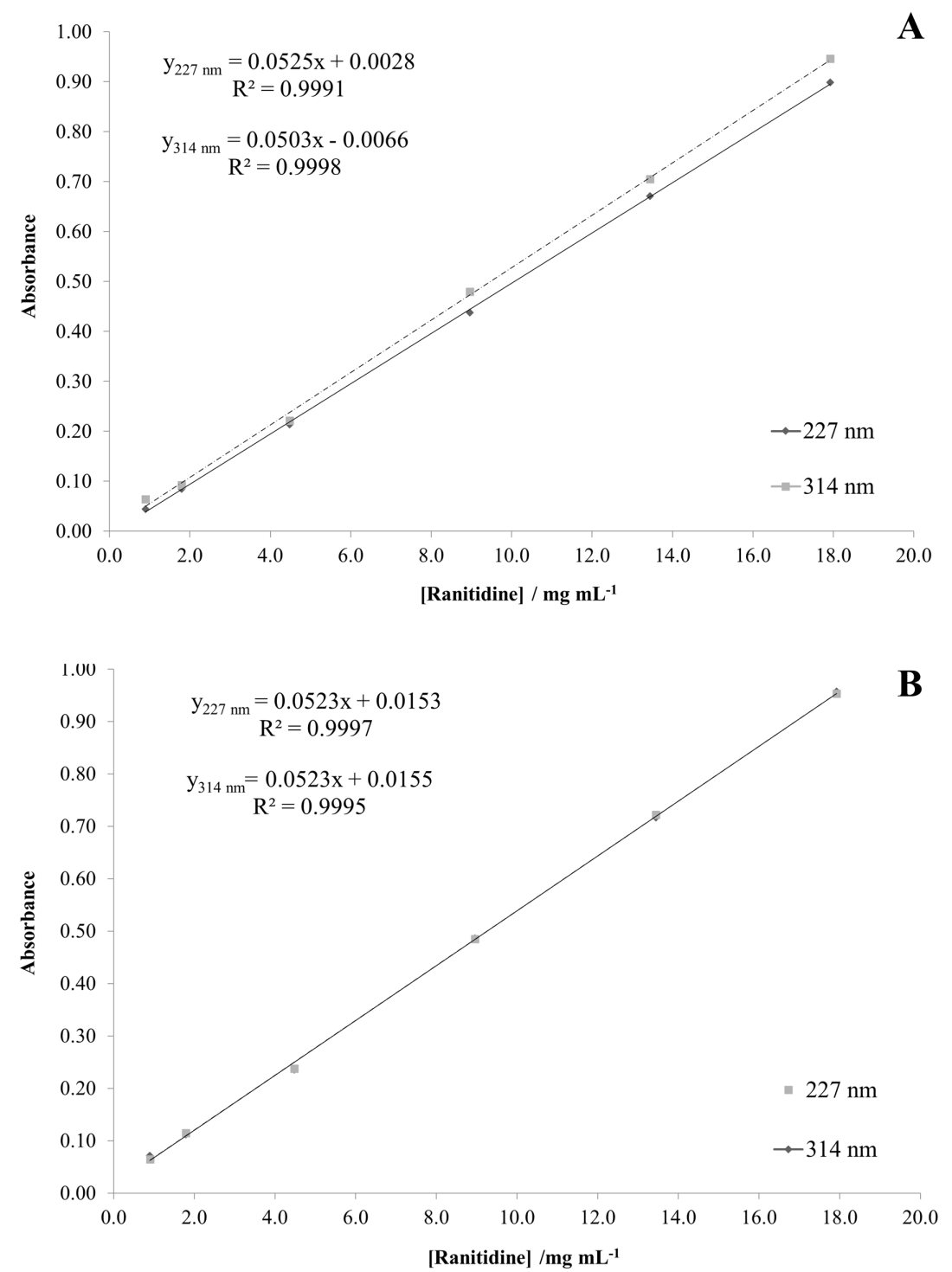

Figure 3 - Standard calibration curves for ranitidine obtained at $227 \mathrm{~nm}$ and $314 \mathrm{~nm}$, by external calibration (A) and standard addition (B) methods. Note the overlap of data points/calibration curve in curve B.

Figura 3 - Curvas de calibração padrão para ranitidina obtidas a $227 \mathrm{~nm}$ e $314 \mathrm{~nm}$, pelos métodos de calibração externa (A) e adição padrão (B). Notar a sobreposição de pontos de dados/curva de calibração no painel B. 
of the European Pharmacopoeia for ranitidine tablets. Students' average results was $148 \pm 1 \mathrm{mg}$ of ranitidine, equivalent to a good agreement with the tolerable and expected percentage range of the labelled claim as set forth by Pharmacopoeia $(22,23)$.

\section{Conclusion}

The experimental procedure presented for quantification of the water-soluble drug ranitidine, a histamine $\mathrm{H}_{2}$ receptor antagonist, represents a non-hazardous, simple, and reproducible laboratory experiment that can be conducted at an undergraduate level.

The use of UV spectrophotometry allowed for the quantification of ranitidine in the tablets analysed. An average content of $148 \pm 1 \mathrm{mg}$ of ranitidine was calculated, in good agreement with the amount claimed on the product label and in accordance with the specifications of the European Pharmacopoeia. The ratio, between the maximum absorbances at 227 $\mathrm{nm}$ and $314 \mathrm{~nm}$, were 1.05 and 1.07 for standard stock and sample solutions, respectively, also in conformity to Pharmacopoeia $(22,23)$. The methods used were found to be simple, rapid, accurate, precise, and easily implemented in a three-hour laboratory class. Moreover, the requirement of readily available reagents that are inexpensive and safe to handle makes the analytical method economical and environmentally friendly. The proposed quantitation of ranitidine from commercial tablets can be made at $227 \mathrm{~nm}$ and/or at $314 \mathrm{~nm}$ using an external standard method and/or the standard addition method, showing relative error in the same order of magnitude.

\section{Authors Contributions Statement}

P.R., L.R., M.N., P.P., C.F. - conceptualization and study design; M.N. - experimental implementation; M.N., P.P. - data analysis; M.N., P.P. - drafting, editing and reviewing; M.N- figures and graphics; P.R., L.R., M.N., P.P., C.F - supervision and final writing. ranitidina ( $\mathrm{mg} /$ tablete) na amostra farmacêutica e o valor obtido é comparado com a alegação rotulada do fabricante e com as especificações da Farmacopeia Europeia para comprimidos de ranitidina. Os resultados médios dos estudantes são de $148 \pm 1 \mathrm{mg}$ de ranitidina, estando concordante com a gama percentual tolerável e esperada da alegação rotulada, conforme estabelecido pela Farmacopeia $(22,23)$.

\section{Conclusão}

O procedimento experimental apresentado para quantificação do medicamento hidrossolúvel ranitidina, um antagonista do recetor de histamina $\mathrm{H}_{2}$, representa uma experiência laboratorial não perigosa, simples e reprodutível que pode ser conduzida a um nível de graduação.

A utilização da espectrofotometria UV permitiu a quantificação da ranitidina nos comprimidos analisados. Foi calculado um teor médio de $148 \pm 1 \mathrm{mg}$ de ranitidina, de acordo com as especificações da Farmacopeia Europeia, em concordância com a quantidade pedida pelo rótulo. A relação, entre as absorvâncias máximas a $227 \mathrm{~nm}$ e $314 \mathrm{~nm}$, é de 1,05 e 1,07 para as soluções padrão, mãe e amostra, respetivamente, também em conformidade com a Farmacopeia $(22,23)$.

Os métodos utilizados foram considerados simples, rápidos, exatos, precisos e facilmente implementados numa classe laboratorial de três horas. Além disso, a exigência de reagentes facilmente disponíveis que são baratos e seguros de manusear torna o método analítico um método confiável e também económico. A quantificação proposta de ranitidina em comprimido pode ser utilizada tanto a $227 \mathrm{~nm}$ e/ou a $314 \mathrm{~nm}$ usando os método padrão externo e/ou de adição padrão, mostrando erro relativo na mesma ordem de grandeza.

\section{Declaração sobre as contribuições do autor}

P.R., L.R., M.N., P.P., C.F. - conceção e desenho do estudo; - M.N implementação experimental; M.N., P.P. - análise de dados; M.N., P.P - redação, edição e revisão; M.N - figuras e gráficos; P.R., L.R., M.N., P.P., C.F - supervisão e redação final. 


\section{Funding}

This research was funded by Fundação para a Ciência e a Tecnologia (FCT, Portugal), through projects UIDP/04567/2020 and UIDB/04567/2020. P.P. Gratefully acknowledges the support of the CERENA strategic project FCT-UID/ECI/04028/2019.

\section{Acknowledgments}

The authors acknowledge all the participants.

\section{Conflict of interest}

The authors declare that there is no financial or personal relationship that could present a potential conflict of interests.

\section{Financiamento}

Este trabalho é financiado por fundos nacionais através daFCT - Fundação para a Ciência e Tecnologia, ao abrigo dos projetos UIDB/04567/2020 e UIDP/04567/2020. P.P. agradece o apoio da CERENA ao abrigo projeto estratégico FCT-UID/ECI/04028/2019.

\section{Agradecimentos}

Os autores agradecem a todos os participantes.

\section{Conflito de interesses}

Os autores declaram que não existe qualquer relação financeira ou pessoal que possa apresentar um potencial conflito de interesses. 


\section{References / Referências}

1. Görög, S. (1995). UV-visible spectrophotometry in pharmaceutical analysis. CRC Press, Boca Raton, 1995.

2. Egts, H., Durben, D. J., Dixson, J. A., \& Zehfus, M. H. (2012). A Multicomponent UV Analysis of $\alpha$ - and $\beta$-Acids in Hops. Journal of Chemical Education, 89, 117-120.

3. Kimaru, I. W., Zhao, F., \& Chichester, K. (2010). Spectrophotometric quantification of ibuprofen release in dissolution testing. A pharmaceutical analysis experiment for instrumental analysis laboratory. The Chemical Educator, 15, 484-487.

4. Mbindyo, J. K. N., \& Brown, A. K. (2010). Investigating UV-Blocking Properties of Sunscreens on the Microscale. J. Chem. Educ., 87, 1388.

5. Andersen, J. E. T. (2009). Exercise in quality assurance: A laboratory exercise. Journal of Chemical Education, 86, $733-737$.

6. Reid, K. R., Meyerhoff, M. E., \& Mitchell-Koch, J. T. (2008). Salicylate detection by complexation with iron(III) and optical absorbance spectroscopy. An undergraduate quantitative analysis experiment. Journal of Chemical Education, 85, 1658-1659.

7. Dwyer, T. J., Fillo, \& J. D. (2006). Assaying $\alpha$-dicarbonyl compounds in wine: A complementary GC-MS, HPLC and visible spectrophotometric analysis. Journal of Chemical Education, 83, 273-276.

8. Mouer, H. P., Zanella, A., \& Poon, T. (2006). An introduction to UV-Vis spectroscopy using sunscreens. Journal of Chemical Education, 83, 769.

9. Beckers, J. L. (2004). The determination of caffeine in coffee: Sense or nonsense? Journal of Chemical Education, 81, 90-93.

10. Patterson, B. M., Danielson, N. D., Lorigan, G. A., \& Sommer, A. S. (2003). Analytical spectroscopy using modulator systems. Journal of Chemical Education, 80, 1460-1463.

11. Byrd, H., \& O’Donell, S. E. (2003). A General Chemistry Laboratory Theme: Spectroscopic Analysis of Aspirin. J. Chem. Educ., 80, $174-176$.

12. Aberásturi, F., Jiménez, A. I., Jiménez, F., \& Arias, J. J. (2001). UV-Visible first-derivative spectrophotometry applied to an analysis of a vitamin mixture. Journal of Chemical Education, 78, 793-795.

13. Aroti, A., \& Leontidis, E. (2001). Simultaneous determination of the ionization constant and the solubility of sparingly soluble drug substances. A physical chemistry experiment. Journal of Chemical Education, 78, 786-788.

14. Ribone, M. É., Pagani, A. P., Olivieri, A. C., \& Goicoechea, H. C. (2000). Determination of the active principle in a syrup by spectrophotometry and principal component regression analysis. An advanced undergraduate experiment involving Chemometrics. Journal of Chemical Education, $77,1330-1333$.

15. Aurian-Blajeni, B., Sam, J., \& Sisak, M. (1999). Sweet chemistry. Journal of Chemical Education, 76, 91-92.

16. McDevitt, V. L., Rodriguez, A., \& Williams, K. R. (1998). Analysis of soft drinks: UV spectrophotometry, liquid chromatography and capillary electrophoresis. Journal of Chemical Education, 75, 625-628.

17. Adams, P. E. (1995). Determining iron content in foods by spectrophotometry. Journal of Chemical Education, 72, $649-651$.

18. Yarnelle, M. K., \& West, K. J. (1989). Modification of an ultraviolet spectrophotometric determination of the active ingredients in APC tablets. Journal of Chemical Education, 66, 601-602.

19. Stolzberg, R. J. (1986). Evaluation of derivative ultraviolet spectrometry for determining saccharin in cola and other matrices: An instrumental methods experiment. Journal of Chemical Education, 63, 351-353.

20. Van Atta, R. E. (1979). Ultraviolet spectrophotometric determination of caffeine in cola Drinks: An organic analytical experiment. Journal of Chemical Education, 56, 666.

21. Fernandez, L. T., Mannett, K., \& Frederick H. (1978). Experiment for instrumental analysis. The determination of aspirin by ultraviolet absorption. Journal of Chemical Education, 55, 266.

22. European Pharmacopoeia. (2010). European directorate for the quality of medicines and health care (7th edition), Council of Europe, Strasbourg.

23. Pharmacopeia-National Formulary (USP35 - NF30). (2012). United States pharmacopeial convention, Rockville, USA.

24. Under revision, $95-105 \%$, USP Medicines Compendium (USP-MC). available at https://mc.usp.org (last accessed 06 June 2013 ).

25. International conference on harmonisation of technical requirements for registration of pharmaceuticals for human use. (1994). ICH guideline Q2(R1): Validation of analytical procedures: text and methodology, Geneva, Switzerland.

26. Currie, L. A. (1999). Nomenclature in evaluation of analytical methods including detection and quantification capabilities. Analytica Chimica Acta, 391(2), 105-126. 